\title{
Peningkatan Pengetahuan Remaja dan Pemuda tentang Kesehatan Reproduksi dan Hubungannya dengan Lingkungan Sosial di Palangka Raya
}

Oleh :

Septi Handayani

\begin{abstract}
ABSTRAK
Tulisan ini bertujuan untuk meningkatan pengetahuan remaja dan pemuda tentang kesehatan reproduksi dan hubungannya dengan lingkungan sosial di Palangka Raya. Metode yang digunakan adalah perencanaan partisipatif, pendekatan, dan kegiatan penyuluhan dengan evaluasi pretes dan postes. Kegiatan penyuluhan dihadiri oleh 40 orang peserta (10 orang remaja dan 30 orang pemuda). Hasilnya adalah peningkatan pengetahuan kesehatan reproduksi, penyakit menular seksual dan HIV/AIDS, dan kanker serviks. Simpulannya adalah peningkatan pengetahuan pengetahuan remaja dan pemuda tentang kesehatan reproduksi dan hubungannya dengan lingkungan sosial.
\end{abstract}

Kata Kunci : pengetahuan, kesehatan reproduksi, remaja, pemuda.

\section{A. Pendahuluan}

Menurut Programme of Action of the 1994 United Nations International Conference on Population and Development, kesehatan reproduksi adalah suatu kesempurnaan status fisik, mental, dan kehidupan sosial bukan hanya tanpa adanya penyakit atau kelemahan yang berkaitan dengan fungsi sistem reproduksi dan proses reproduksi (Fahimi \& Ashford, 2011). Kebijakan Nasional Kesehatan Reproduksi di Indonesia menetapkan bahwa Kesehatan Reproduksi mencakup 5 (lima) komponen/program terkait, yaitu Program Kesehatan Ibu dan Anak, Program Keluarga Berencana, Program Kesehatan Reproduksi Remaja, Program Pencegahan dan Penanggulangan Penyakit Menular Seksual (PMS) termasuk HIV/AIDS, dan Program Kesehatan Reproduksi pada Usia Lanjut. Pelaksanaan Kesehatan Reproduksi dilaksanakan dengan menggunakan pendekatan siklus hidup (life-cycle approach) agar diperoleh sasaran yang pasti dan pelayanan yang jelas berdasarkan kepentingan sasaran/klien dengan memperhatikan hak reproduksi mereka (Hanim, D, Santosa, \& Affandi, 2013).

Kondisi yang diharapkan adalah disepakatinya indikator minimal yang harus dicapai oleh program Kesehatan Reproduksi dan disesuaikan dengan Milenium Development Goals. Indikator tersebut adalah : a. Maternal Mortality Ratio, b. Child Mortality Rate, c. Total Fertility Rate, d. Prevalensi infeksi HIV pada umur 15-24 tahun menurun sebesar 20\%, e. Setiap orang mampu melindungi dirinya dari penularan PMS dan HIV/AIDS, f. Peningkatan peran serta masyarakat dalam penanganan kesehatan reproduksi, dan g. Human Development Index (HDI) (Hanim, D, Santosa, \& Affandi, 2013).

Rendahnya pemenuhan hak-hak reproduksi dapat diketahui dengan masih tingginya Angka Kematian Ibu (AKI), Angka Kematian Bayi (AKB) dan Angka Kematian Bawah Lima Tahun (AKBalita). Masalah kesehatan reproduksi perempuan, termasuk perencanaan kehamilan dan persalinan yang aman secara medis juga harus menjadi perhatian bersama, bukan hanya kaum perempuan saja karena hal ini akan berdampak luas dan menyangkut berbagai aspek kehidupan yang menjadi tolok ukur dalam pelayanan kesehatan (Hanim, D, Santosa, \& Affandi, 2013).

Sekitar 1 milyar manusia, adalah remaja yang 85\% hidup di negara berkembang. Banyak remaja yang sudah aktif seksual sehingga beresiko terhadap penyakit menular seksual dan terinfeksi HIV. Remaja berusia antar 15-19 tahun banyak yang melahirkan dan melakukan aborsi (UNPA, 2010). Menurut BKKBN usia yang ideal 20-30 tahun, lebih atau kurang dari usia itu adalah berisiko. Kesiapan untuk hamil dan melahirkan ditentukan oleh: kesiapan fisik, kesiapan mental/emosi/psikologis, dan kesiapan sosial ekonomi. Usia 20 tahun secara fisik dianggap sudah siap (UNPA, 2010). 
Remaja seringkali kekurangan informasi dasar mengenai kesehatan reproduksi. Selain itu, masih ada tuntutan budaya kawin muda hubungan seksual pra nikah, ketidaksetaraan gender, kekerasan seksual, dan pengaruh media massa maupun gaya hidup populer yang mempengaruhi kesehatan reproduksi (UNPA, 2010). Oleh karena itu, kegiatan ini bertujuan untuk meningkatkan pengetahuan remaja dan pemuda tentang kesehatan reproduksi dan hubungannya dengan lingkungan sosial di Palangka Raya.

\section{B. Metode}

Metode pendekatan yang digunakan yaitu sebagai berikut.

4. Metode Perencanaan Partisipatif.

Metode pendekatan yang digunakan yaitu suatu kegiatan perencanaan yang melibatkan masyarakat untuk menumbuhkan rasa keingintahuan dari partisipan/anggota kelompok masyarakat. Pengumpulan data dasar dan informasi mengenai potensi kelompok masyarakat ini dilakukan melalui survei. Pada tahap ini dilakukan pendekatan- pendekatan dan penyamaan persepsi dengan berbagai unsur dalam masyarakat menyangkut potensi kelompok. Data dasar yang dimaksud adalah keadaan sosial budaya dan ekonomi masyarakat, potensi sumber daya manusia, dan sarana prasarana pendukung.

5. Pendekatan terhadap tokoh masyarakat untuk mendapatkan dukungan secara penuh karena peranan para tokoh tersebut terhadap anggota kelompok secara umum.

6. Kegiatan, meliputi antara lain:

- Penyuluhan (mengenai kesehatan reproduksi, penyakit menular seksual dan HIV/AIDS, dan kanker serviks serta hubungannya dengan lingkungan sosial).

- Evaluasi dilakukan dengan cara diuji pre dan post test setelah mendapatkan pengetahuan mengenai kesehatan reproduksi, penyakit menular seksual dan HIV/AIDS, dan kanker serviks serta hubungannya dengan lingkungan sosial.

\section{Hasil dan Pembahasan}

Peserta yang hadir dalam kegiatan ini terdiri dari 2 kelompok yaitu kelompok remaja dan pemuda. Kelompok remaja berjumlah 10 orang (laki-laki 5 orang dan perempuan 5 orang) dan kelompok pemuda berjumlah 30 orang (laki-laki 9 orang dan perempuan 21 orang). Kelompok sasaran telah memenuhi target usia, yaitu remaja (rerata usia 16 tahun) dan pemuda (rerata usia 20 tahun) yang mengalami perubahan organ reproduksi secara anatomi dan fisiologi. Akibat perubahan tersebut muncul banyak pertanyaan yang bila ditanyakan ke orang tua akan memberikan jawaban yang bervariasi. Kebudayaan Indonesia, khususnya Palangka Raya masih tertutup untuk membahas masalah yang berkaitan dengan organ reproduksi dan proses reproduksi (dianggap ,tabu ${ }^{\text {ee }}$ atau tidak layak dibicarakan). Selain itu, pengetahuan orangtua yang terbatas mengenai perubahan anatomi dan fisiologi organ reproduksi manusia juga mengakibatkan orangtua menjadi malas menjawab atau menjawab

„seadanya ${ }^{\text {ee }}$ saja sehingga anak remaja dan pemuda cenderung menggali sendiri informasi yang terjadi pada tubuhnya terutama organ reproduksi dan proses reproduksi pada sumber informasi yang umum digunakan saat ini yaitu media elektronik global atau, ,internet ${ }^{\text {ee }}$. Pengawasan yang tidak baik (tanpa bimbingan) juga dapat mengakibatkan kesalahan persepsi oleh remaja atau pemuda pada saat menggali informasi sendiri. Oleh karena itu, kegiatan ini menghasilkan pengetahuan dengan hasil evaluasi pretes dan postes pada kedua kelompok ditampilkan pada tabel berikut. 
Tabel 1. Pengetahuan kelompok remaja dan pemuda tentang kesehatan reproduksi

\begin{tabular}{|c|c|c|c|c|c|c|c|}
\hline \multirow[t]{2}{*}{ No. } & \multirow[t]{2}{*}{ Pertanyaan } & \multicolumn{2}{|c|}{ Pretes (\%) } & \multicolumn{2}{|c|}{ Postes (\%) } & \multicolumn{2}{|c|}{$\begin{array}{c}\text { Peningkatan } \\
\text { pengetahuan (\%) }\end{array}$} \\
\hline & & Remaja & Pemuda & Remaja & Pemuda & Remaja & Pemuda \\
\hline 1. & $\begin{array}{l}\text { Apakah Anda tahu } \\
\text { nama organ } \\
\text { reproduksi Anda? }\end{array}$ & 0 & 60 & 100 & 100 & 100 & 40 \\
\hline 2. & $\begin{array}{l}\text { Apakah Anda tahu } \\
\text { pertumbuhan dan } \\
\text { perkembangan alat } \\
\text { kelamin sekunder } \\
\text { Anda? }\end{array}$ & 0 & 17 & 100 & 100 & 100 & 83 \\
\hline 3. & $\begin{array}{l}\text { Apakah Anda tahu } \\
\text { pengaruh hormon } \\
\text { terhadap organ } \\
\text { reproduksi Anda? }\end{array}$ & 0 & 7 & 100 & 100 & 100 & 93 \\
\hline 4. & $\begin{array}{l}\text { Apakah Anda tahu } \\
\text { cara merawat } \\
\text { organ reproduksi } \\
\text { Anda? }\end{array}$ & 0 & 75 & 100 & 100 & 100 & 25 \\
\hline 5. & $\begin{array}{l}\text { Apakah Anda tahu } \\
\text { mekanisme } \\
\text { terjadinya } \\
\text { kehamilan? }\end{array}$ & 0 & 77 & 100 & 100 & 100 & 23 \\
\hline 6. & $\begin{array}{l}\text { Apakah Anda tahu } \\
\text { cara mengelola } \\
\text { gairah seksual } \\
\text { Anda? }\end{array}$ & 0 & 100 & 100 & 100 & 100 & 0 \\
\hline 7. & $\begin{array}{l}\text { Apakah Anda tahu } \\
\text { apa saja } \\
\text { penyimpangan } \\
\text { terhadap } \\
\text { pengelolaan gairah } \\
\text { seksual? }\end{array}$ & 1 & 27 & 100 & 100 & 90 & 73 \\
\hline 8. & $\begin{array}{l}\text { Apakah Anda tahu } \\
\text { pengaruh } \\
\text { penyimpangan } \\
\text { terhadap } \\
\text { pengelolaan gairah } \\
\text { seksual terhadap } \\
\text { lingkungan } \\
\text { sosial/masyarakat? }\end{array}$ & 1 & 23 & 100 & 100 & 90 & 77 \\
\hline 9. & $\begin{array}{l}\text { Apakah Anda tahu } \\
\text { pengaruh } \\
\text { kehamilan di luar } \\
\text { pernikahan } \\
\text { terhadap } \\
\text { lingkungan } \\
\text { sosial/masyarakat? }\end{array}$ & 3 & 43 & 100 & 100 & 70 & 57 \\
\hline
\end{tabular}


Keterangan : Nilai pretes dan postes adalah jumlah peserta yang menjawab pertanyaan dengan benar.

Berdasarkan tebel 1, didapatkan bahwa terjadi peningkatan pengetahuan remaja dan pemuda mengenai kesehatan reproduksi. Pengetahuan yang meningkat yaitu mengenai nama organ reproduksi, pertumbuhan dan perkembangan alat kelamin sekunder manusia, pengaruh hormon pada organ reproduksi, dan mekanisme terjadinya kehamilan. Pengetahuan mengenai pengeloaan gairah seksual padaa remaja terjadi peningkatan tetapi pada pemuda tidak terjadi perubahan pengetahuan karena diawal tes (pretes) kelompok pemuda telah mengetahui bagaimana mengelola gairah seksual yang telah dialami dalam perjalan usia sehingga tidak terjadi penyimpangan. Pengetahuan remaja dan pemuda mengenai pengaruh penyimpangan pengelolaan gairah seksual (misalnya mencoba berhubungan seksual sebelum menikah, masturbasi, atau suka mengkonsumsi hal-hal terkait pornografi) dan kehamilan di luar pernikanan pada lingkungan sosial (misalnya stigma dari lingkungan sosial mengakibatkan munculnya rasa malu dan menarik diri, tingkat kejahatan misalnya aborsi, pembunuhan bayi dan bunuh diri).

Tabel 2. Pengetahuan mengenai Penyakit Menular Seksual dan HIV/AIDS

\begin{tabular}{|c|c|c|c|c|c|c|c|}
\hline \multirow[t]{2}{*}{ No. } & \multirow[t]{2}{*}{ Pertanyaan } & \multicolumn{2}{|c|}{ Pretes (\%) } & \multicolumn{2}{|c|}{ Postes (\%) } & \multicolumn{2}{|c|}{$\begin{array}{c}\text { Peningkatan } \\
\text { pengetahuan }(\%)\end{array}$} \\
\hline & & Remaja & Pemuda & Remaja & Pemuda & Remaja & Pemuda \\
\hline 1. & $\begin{array}{l}\text { Apakah Anda tahu } \\
\text { definisi/pengertian } \\
\text { PMS dan } \\
\text { HIV/AIDS? }\end{array}$ & 30 & 47 & 100 & 100 & 70 & 53 \\
\hline 2. & $\begin{array}{l}\text { Apakah Anda tahu } \\
\text { penyebab } \\
\text { terjadinya PMS } \\
\text { dan HIV/AIDS? }\end{array}$ & 10 & 50 & 100 & 100 & 90 & 50 \\
\hline 3. & $\begin{array}{l}\text { Apakah Anda tahu } \\
\text { cara penularan } \\
\text { PMS dan } \\
\text { HIV/AIDS? }\end{array}$ & 30 & 6 & 100 & 100 & 70 & 93 \\
\hline 4. & $\begin{array}{l}\text { Apakah Anda tahu } \\
\text { komplikasi PMS } \\
\text { dan HIV/AIDS? }\end{array}$ & 10 & 75 & 100 & 100 & 90 & 25 \\
\hline 5. & $\begin{array}{l}\text { Apakah Anda tahu } \\
\text { pengaruh PMS } \\
\text { dan HIV/AIDS } \\
\text { terhadap } \\
\text { lingkungan } \\
\text { sosial/masyarakat? }\end{array}$ & 10 & 10 & 100 & 100 & 90 & 90 \\
\hline 6. & $\begin{array}{l}\text { Apakah Anda tahu } \\
\text { cara pencegahan } \\
\text { PMS dan } \\
\text { HIV/AIDS? }\end{array}$ & 10 & 47 & 100 & 100 & 90 & 53 \\
\hline
\end{tabular}

Keterangan : Nilai pretes dan postes adalah jumlah peserta yang menjawab pertanyaan dengan benar.

Berdasarkan tebel 2, didapatkan bahwa terjadi peningkatan pengetahuan remaja dan pemuda mengenai penyakit menular seksual (PMS) dan HIV/AIDS. Peningkatan pengetahuan tersebut yaitu mengenai: 
1. Pengertian/definisi PMS dan HIV/AIDS:

- Penyakit menular seksual yaitu penyakit yang ditularkan dengan cara berhubungan seksual.

- HIV/AIDS yaitu penyakit penurunan kekebalan tubuh yang dapat ditularkan dengan cara berhubungan seksual.

2. Penyebab PMS (bakteri, virus, jamur, atau parasit) dan penyebab HIV/AIDS (virus).

3. Cara penularan (melalui hubungan seksual antara heteroseksual atau homoseksual baik secara oral, anal, ataupun vaginal).

4. Komplikasi (kekebalan menurun, penyebaran organisme atau toksin penyebab penyakit ke organ vital tubuh, sampai kematian).

5. Pengaruh PMS dan HIV/AIDS terhadap lingkungan sosial (menurunnya produktivitas individu dalam berhubungan sosial akibat stigma dan penyakit yang dideritanya sehingga muncul penarikan diri, rasa bersalah, malu, ketidakharmonisan rumahtangga karena saling menyalahkan, masa depan anak terancam).

6. Cara pencegahannya (setia pada pasangan yang sudah disahkan oleh negara dan agama, tidak mencoba berhubungan seksual sebelum menikah terutama menggunakan penjaja seks komersial, menggunakan alat pengaman (kondom) pada pasangan yang salah satunya telah tertular).

Tabel 3. Pengetahuan mengenai Kanker Serviks

\begin{tabular}{|l|l|l|l|l|l|l|l|}
\hline \multirow{2}{*}{ No. } & \multicolumn{2}{|c|}{ Pertanyaan } & \multicolumn{2}{c|}{ Pretes (\%) } & \multicolumn{2}{c|}{ Postes (\%) } & \multicolumn{2}{c|}{$\begin{array}{c}\text { Peningkatan } \\
\text { pengetahuan (\%) }\end{array}$} \\
\cline { 3 - 8 } & \multicolumn{2}{|c|}{ Remaja } & Pemuda & Remaja & Pemuda & \multicolumn{1}{c|}{ Remaja } & \multicolumn{1}{c|}{ Pemuda } \\
\hline 1. & $\begin{array}{l}\text { Apakah Anda tahu } \\
\text { definisi/pengertian } \\
\text { kanker serviks? }\end{array}$ & 10 & 60 & 100 & 100 & 90 & 40 \\
\hline 2. & $\begin{array}{l}\text { Apakah Anda tahu } \\
\text { penyebab } \\
\text { terjadinya kanker } \\
\text { serviks? }\end{array}$ & 10 & 73 & 100 & 100 & 90 & 27 \\
\hline 3. & $\begin{array}{l}\text { Apakah Anda tahu } \\
\text { mekanisme } \\
\text { terjadinya kanker } \\
\text { serviks? }\end{array}$ & 10 & 33 & 100 & 100 & 90 & 67 \\
\hline 4. & $\begin{array}{l}\text { Apakah Anda tahu } \\
\text { komplikasi kanker } \\
\text { serviks? }\end{array}$ & 50 & 33 & 100 & 100 & 50 & 67 \\
\hline 5. & $\begin{array}{l}\text { Apakah Anda tahu } \\
\text { cara pencegahan } \\
\text { kanker serviks? }\end{array}$ & 30 & 33 & 100 & 100 & 70 & 67 \\
\hline
\end{tabular}

Keterangan : Nilai pretes dan postes adalah jumlah peserta yang menjawab pertanyaan dengan benar.

Berdasarkan tebel 3, didapatkan bahwa terjadi peningkatan pengetahuan remaja dan pemuda mengenai penyakit kanker serviks. Peningkatan pengetahuan tersebut yaitu mengenai:

1. Pengertian kanker serviks yaitu perubahan sel mulut rahim menjadi sel ganas yang progresif dan destruktif.

2. Penyebab kanker serviks yaitu perubahan sel mulut rahim akibat terinfeksi virus Human Pappiloma. 
3. Mekanisme terjadi kanker serviks yaitu adanya penghambatan oleh HPV pada gen yang menekan terjadinya kanker sehingga tidak adanya perlindungan terhadap sel kanker dan kanker pun berkembang.

4. Pencegahan dilakukan dengan cara tidak berhubungan seksual sebelum usia 16 tahun (karena sel-sel mulut rahim mudah mengalami perubahan menjadi ganas) dan pada pria harus menggunakan pelindung pada saat berhubungan bila pasangan terbukti mengalami kanker agar tidak terjadi penularan virus dan mengakibatkan kanker pada penis.

\section{Simpulan dan Saran}

Simpulan yang didapat dari kegiatan yaitu pertama, meningkatnya pengetahuan pemuda dan remaja mengenai organ reproduksi pria dan wanita secara anatomi dan fisiologi serta cara perawatan organ reproduksi dan pengelolaan perubahan lonjakan gairah seksual akibat perubahan anatomi dan fisiologi organ reproduksi secara positif; kedua, meningkatnya pengetahuan remaja dan pemuda tentang penyakit menular seksual dan HIV/AIDS dan kanker serviks.

Saran yang diberikan yaitu perlu dilakukan kegiatan penyuluhan dengan judul yang sama kepada orang tua atau kelompok remaja yang lain (yang baru) agar dapat mendapat infomasi yang tepat mengenai organ reproduksi pria dan wanita secara anatomi dan fisiologi agar dapat merawat organ reproduksi dan mengelola diri akibat perubahan lonjakan gairah seksual akibat perubahan anatomi dan fisiologi organ reproduksi secara positif.

\section{Daftar Pustaka}

Fahimi, FR and Ashford, L, 2008, Sexual \& Reproductive Health in the Middle East and North Africa A Guide for Reporters, population Reference Beareau.

Hanim, D, Santosa, \& Affandi, 2013, Kesehatan Reproduksi, Field Lab Fakultas

Kedokteran Universitas Sebelas Maret.

Rachmawati, IN, 2010, Pelatihan Kesehatan Reproduksi Remaja Untuk Mencegah

Kematian Perinatal.

UNPFA, 2000, .Kesehatan Reproduksi Remaja: Membangun perubahan yang bermakna, Out Look vol. 16. 